\title{
THE EVALUATION OF THE CAUSES OF RETAINING WALL STRUCTURE FAILURE AT A RIVER BASED ON SNI 2847:2013
}

\section{EVALUASI PENYEBAB KEGAGALAN BANGUNAN TURAP DI SEBUAH SUNGAI BERDASARKAN SNI 2847:2013}

\author{
Tri Handayani ${ }^{1}$, Sudarmadi ${ }^{1}$ \\ ${ }^{1}$ National Laboratory for Structural Strength Technology \\ Agency for the Assessment and Application of Technology \\ e-mail: tri.handayani@bppt.go.id, sudarmadi@bppt.go.id
}

\begin{abstract}
In this paper, the application of SNI 2847:2013 in the evaluation of the case of a retaining wall failure is presented. The method is the analytical retaining wall evaluation, which consisted of visual inspection in the field, depth measurement of pile and sheet pile, and the quality test of concrete material. The data were used as input in structure modeling using Finite Element Method (FEM) software to calculate each structural member's required strength $\left(R_{u}\right)$. The calculation was done to obtain the design strength $\left(\varnothing R_{n}\right)$ of the structural member. The retaining wall is considered safe if its design strength is greater than or equal to the required strength or $\emptyset R_{n} \geq R_{u}$. If this condition cannot be fulfilled, the retaining wall is considered failed, and then the causes of failure would be performed. The result showed that the depth of the pile and sheet pile is less than the required minimum depth, and concrete quality is below the specification mentioned in the as-built drawing data. According to structural analysis and calculation of site investigation data, it could be known that the causes of retaining wall failure are the design strength is smaller than the required strength and the vertical moment due to its self-weight is much smaller than the horizontal moment due to soil and water pressure, so it causes the structural sliding.
\end{abstract}

Keywords: Retaining Wall Failure; Retaining Wall Evaluation; Required Strength; Design Strength; Sliding

\begin{abstract}
Abstrak
Pada makalah ini disajikan aplikasi SNI 2847:2013 dalam evaluasi dari kasus kegagalan sebuah bangunan turap. Metode yang digunakan adalah evaluasi bangunan secara analitis yang terdiri dari pemeriksaan kerusakan secara visual di lapangan, pemeriksaan kedalaman pile dan sheetpile dan pengujian mutu bahan beton. Data tersebut sebagai input dalam pemodelan struktur dengan Finite Element method (FEM) dan diperoleh kuat perlu $\left(R_{u}\right)$ masing-masing komponen. Perhitungan juga dilakukan terhadap kuat rencana $\left(\emptyset R_{n}\right)$ dari masing-masing komponen. Struktur dikatakan aman jika kuat rencana lebih besar atau sama dengan kuat perlu atau $\emptyset R_{n} \geq R_{u}$. Kemudian dilakukan penentuan penyebab kegagalan. Hasil penelitian menunjukkan bahwa kedalaman pile dan sheetpile masih kurang dari kedalaman minimum yang diperlukan dan kualitas material beton tidak sesuai dengan data dari as built drawing. Berdasarkan hasil analisis struktur serta perhitungan dari data penyelidikan tanah diketahui bahwa penyebab kegagalan bangunan turap adalah kuat rencana lebih kecil dari kuat perlu dan momen vertikal akibat berat sendiri jauh lebih kecil dari momen horisontal akibat tekanan tanah dan tekanan air sehingga terjadi guling.
\end{abstract}

Kata kunci : Kegagalan Bangunan Turap; Evaluasi Bangunan Turap; Kuat Perlu; Kuat Rencana; Guling

Received: 10 November 2020, Revised: 10 November 2020, Accepted: 10 December 2020 


\section{INTRODUCTION}

A retaining wall is a thin vertical wall used for retaining soil and retaining water at soil excavation. Due to easier and cheaper construction cost, retaining wall usually used for a temporary retaining wall at soil excavation, marine construction, earth retaining wall, cofferdam, etc. Retaining wall is not suitable to retain a high landfill because it will need a large surface area of sheet pile. Retaining wall is not suitable for soil with much rock due to the difficulty of pile erection ${ }^{1)}$.

Failure of a structure, including retaining wall structure, could happen in the construction process and after the structure's construction or in-service life. Failure of a structure is caused by overloading, improper planning, the use of material that does not meet the requirements, unsuitable construction process, and the environmental effect that was not anticipated in design'2).

The researcher in Indonesia has conducted some research related to the collapse or failure of the structure. They are Wiyana ${ }^{3)}$, (shak ${ }^{4)}$, Pranata and Elvira5), Ismail(6), and Fauzan ${ }^{7}$. Wiyana ${ }^{3)}$ analyzed the collapse of structure from a technical perspective, Ishak ${ }^{4)}$ analyzed the failure of the structure due to corrosion of the reinforcing steel bar, Pranata and Elvira ${ }^{5}$ analyzed the failure of building structure using Finite Element Software, Ismail6) made identification, analyzed and repaired the failure of building and Fauzan ${ }^{7}$ analyzed and repaired of the building structure.

The background of this study is a failure of retaining wall structure during the construction process. The retaining wall is collapsed due to a flood at the river. This study aims to find out the causes of the collapse of the retaining wall structure. An investigation is conducted to evaluate the retaining wall structure based on $\mathrm{SNI}$ 2847:2013 ${ }^{8)}$.

\section{MATERIALS AND METHOD}

The object of this study is a retaining wall structure at a river. A retaining wall structure has many types based on the materials used, the shape, and the function. Based on the materials used, there are three types of retaining wall structure: wood retaining wall, concrete retaining wall, and steel retaining wall. According to the shape and the function, there are four types of retaining wall structure: cantilever retaining wall, anchorage retaining wall, platform retaining wall with pile supporting, and retaining wall for cellular cofferdam ${ }^{1)}$.

A platform retaining wall is a retaining wall structure that retained lateral earth pressure. The platform is supported by piles. A structure may build on the platform. Piles support a platform and also reduce the lateral load of retaining wall ${ }^{1}$.

Retaining wall structure receives lateral load from active and passive earth pressure load, uniform load from landfill, the groundwater level is not the same on both sides of retaining wall, earthquake load, shockwave load, ship traction load, etc.

Strength of structural analysis is needed to determine the reliability of the structure. Structure or a part of the structure will meet the strength requirement if the required strength is lower or the same as the design strength. The required strength is analyzed from the working load, dead load, live load, wind load, earthquake load, etc. The reliability of structure is presented as in Equation 1 below ${ }^{3)}$

\section{Required strength $\leq$ Design strength}

$$
R_{u} \leq \varnothing R_{n}
$$

$R_{n}$ is design strength and $R_{u}$ is the required strength or reaction force from the working load on structure such as moment, axial force, shear force, and torsion. $\varnothing$ is the reduction strength factor.

There are three methods to evaluate the existing structure based on SNI 2847:2013, which are analytical method, loading test method, and the combination of both analytical and loading test method ${ }^{8)}$. The strength of structure evaluation in this study used the analytical method. The procedure for evaluating the existing structure with an analytical method is presented in Figure $1^{9 \text { ) }}$.

Structural analysis of retaining wall use finite element method software, which is SAP 2000 software. The simplicity of the structural modeling is needed in this study due to a difference between the model and the structure's real condition. In modeling, some assumptions are usually used to solve the problem, but this assumption must be close to the structure's real condition. The retaining wall structure can be modeled as a plate element and beam element, as shown in Figure 2. Joint on this structure is modeled as fixed joint ${ }^{10)}$.

Retaining wall structure can be modeled in 2-dimensional modeling or 3-dimensional modeling. The platform is modeled as a plate bending element. Pile, sheet pile, and beam are modeled as beam elements (frame 
element). Support at the bedrock of pile and sheet pile is modeled as a fixed end.

The retaining wall structure in this study is categorized as a concrete retaining wall structure based on its material. Based on its shape, the retaining wall is categorized as a platform retaining wall structure with a supporting pile. The retaining wall structure consists of a plate (platform), pile, sheet pile, and beam.

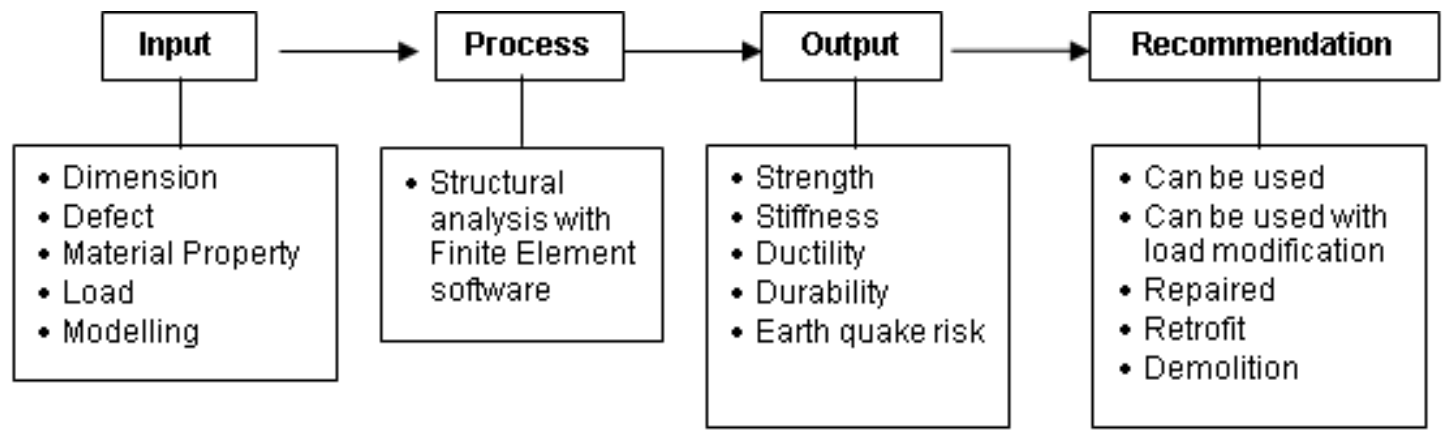

Figure 1.

Procedure for The Evaluation of Existing Structure with the Analytical Method ${ }^{9}$

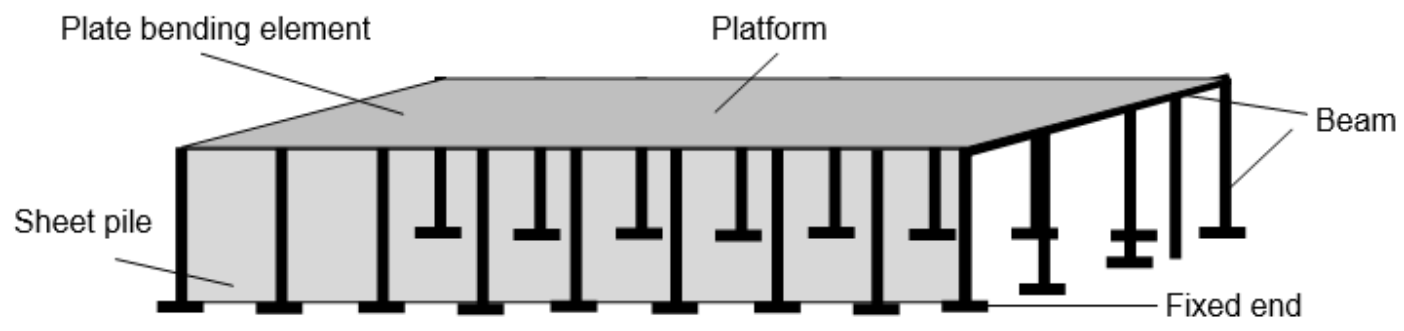

Figure 2.

Element Type of Retaining Wall Structure Modelling ${ }^{10}$

Dimension of platform is $8100 \times 410 \times 30$ $\mathrm{mm}^{3}$, dimension of pile is $40 \times 40 \times 2200 \mathrm{~mm}^{3}$, dimension of sheet pile is $100 \times 33.5 \times 1200$ $\mathrm{mm}^{3}$ and dimension of beam is $40 \times 50 \mathrm{~mm}^{2}$.

Figure 3 and Figure 4 show the equipment for the pile's dimension and depth measurement. The equipment for dimension measurement consists of a tape meter, caliper, and distometer. Equipment for the pile's depth measurement is Pile Integrity Tester.

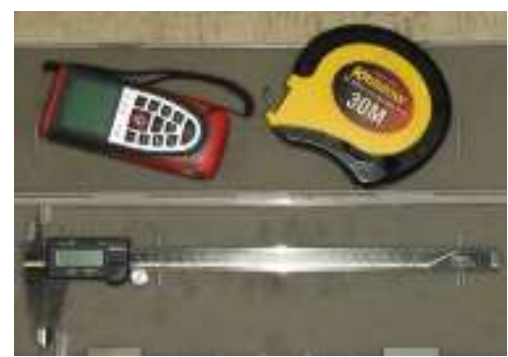

Figure 3

Dimension Measurement Equipment: (a) Distometer, (b) Roll meter and (c) Caliper

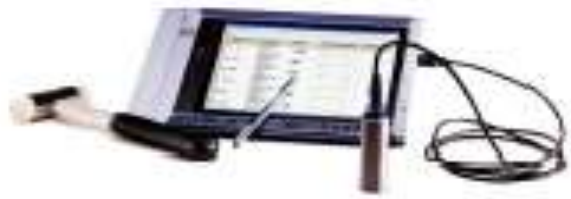

Figure 4.

Pile Integrity Tester

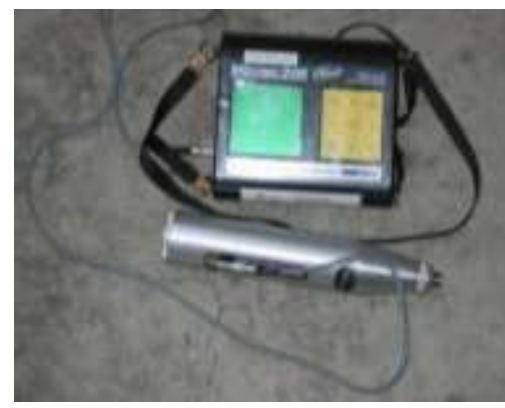

Figure 5.

Digischmidt Hammer Tester 


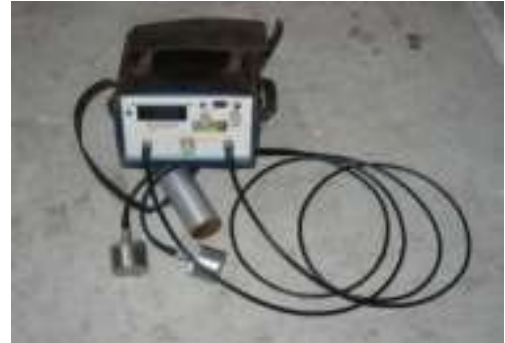

Figure 6.

Portable PUNDIT

Equipment to check the quality of concrete consists of Digischmidt Hammer, PUNDIT, core drill, and universal testing machine. The set of equipment to check the quality of concrete is presented in Figure 5 to Figure 8.

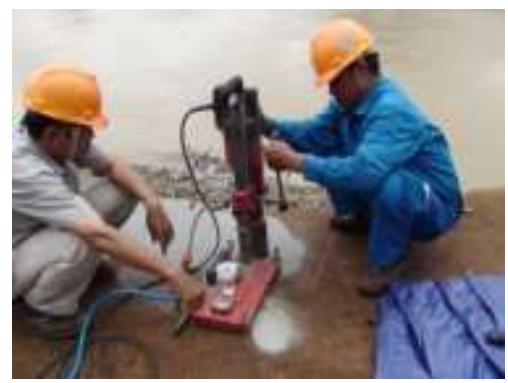

Figure 7.

Core Drilled Machine

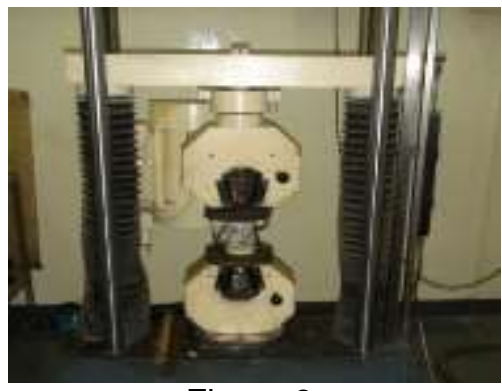

Figure 8

Universal Testing Machine

Quality of concrete measurement by Digischmidt hammer tester are conducted on the platform in 8 locations, pile in 22 locations, and sheet pile in 8 locations. Quality of concrete measurement by ultrasonic pulse velocity method is conducted on the platform in 8 locations, pile in 12 locations, and sheet pile in 6 locations. Sampling for core drill is conducted on the platform in 8 locations.

\section{RESULTS AND DISCUSSION}

The major damage to the retaining wall structure is the collapse of the structure in the middle section. The water flow at the river base causes the scouring at pile and sheet pile foundation. This scouring made the pile and sheet pile sliding. The pile sliding and vertical load from the structure's self-weight and lateral earth pressure caused an unbalanced condition between the working load and the structure's required strength. Because of this unbalanced condition, the retaining wall structure turned around and collapsed at the middle section. The damage and collapse of the retaining wall structure are presented in Figure 9 and Figure 10.

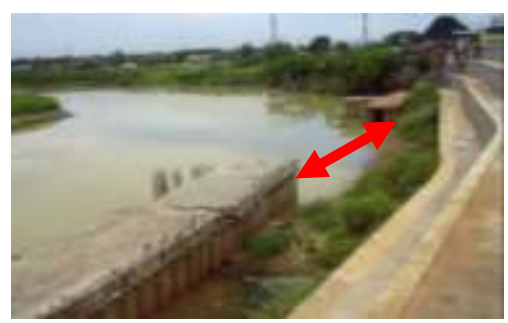

Figure 9.

A Collapsed Structure at the Middle Section

There are many damages to the existing retaining wall structure, including spalling, cracking, and broken at joint pile and column. Crack width is more than $0.4 \mathrm{~mm}$. The damages can cause corrosion in the concrete structure.

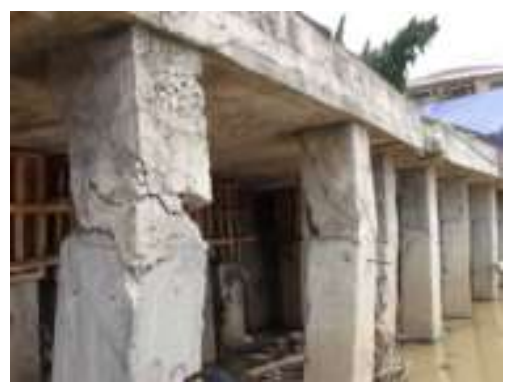

Figure 10.

Broken Pile at Joint

Table 1.

Ultrasonic Pulse Velocity of Concrete

\begin{tabular}{lcc}
\hline \multirow{2}{*}{ Quality of concrete } & \multicolumn{2}{c}{ Ultrasonic pulse velocity $(\mathrm{km} /$ det $)$} \\
\cline { 2 - 3 } Very good & Maholtra & Leslie \& Cheesman \\
Good & $>4.6$ & $>5.0$ \\
Fair & $3.7-4.6$ & $4.0-5.0$ \\
Poor & $3.0-3.7$ & $3.0-4.0$ \\
Very poor & $2.1-3.0$ & \\
\hline
\end{tabular}


Table 2 .

Quality of Concrete Test Results by PUNDIT

\begin{tabular}{clccc}
\hline No. & Structure & $\begin{array}{c}\text { Ultrasonic pulse } \\
\text { velocity }(\mathrm{km} / \mathrm{sec})\end{array}$ & $\begin{array}{c}\text { Quality of } \\
\text { concrete }\end{array}$ & $\begin{array}{c}\text { Concrete strength estimation } \\
(\mathrm{MPa})\end{array}$ \\
\hline 1. & Platform & 3.49 & Fair & 17.99 \\
2. & Pile & 4.05 & Good & 32.18 \\
3. & Sheet pile & 4.09 & Good & 29.66 \\
\hline & Average & 3.89 & Good & 27.22 \\
\hline
\end{tabular}

Table 3.

Recapitulation of Concrete Test Results

\begin{tabular}{llccc}
\hline \multirow{2}{*}{ No. } & \multirow{2}{*}{ Method } & \multicolumn{3}{c}{ Compressive strength of concrete (MPa) } \\
\cline { 2 - 5 } & & Platform & Pile & Sheet pile \\
\hline 1 & PUNDIT & 17.99 & 32.18 & 29.66 \\
2 & Digischmidt Hammer & 16.59 & 35.30 & 41.35 \\
3 & Core Drill & 17.56 & - & - \\
\hline
\end{tabular}

The result of measurement by PUNDIT is ultrasonic pulse velocity at the inside of concrete. The value of ultrasonic pulse velocity is from $2.97 \mathrm{~km} / \mathrm{sec}$ until $4.60 \mathrm{~km} / \mathrm{sec}$. Based on the value of the ultrasonic pulse velocity result, one can conclude that the quality of concrete is ranging from poor to good and averagely is acceptable based on a result of Maholtra's study (see Table 1). The ultrasonic pulse velocity is used to estimate concrete strength. The result is shown in Table 2. The result of concrete quality measurement from three methods is shown in Table 3.

The measurement result showed differences in the concrete quality from one measurement method and different measurement methods. Different estimation results of concrete strength in the same method mean a variation of concrete strength. Concrete strength would not be the same quality in each area because the concrete material is not homogeny. Many factors can influence the concrete strength in a construction process, such as mix design, source of the material (quarry location), mixing process, transportation, and compacting until the curing process. Concrete strength result from PUNDIT method is closed to core drill method. Structural analysis with finite element software used the data of concrete strength from PUNDIT method. The platform structure used the concrete strength of $216.75 \mathrm{~kg} / \mathrm{cm}^{2}$, the pile structure used the concrete strength of $387.72 \mathrm{~kg} / \mathrm{cm}^{2}$, and the sheet pile used the concrete strength of $357.33 \mathrm{~kg} / \mathrm{cm}^{2}$. The concrete strength of the platform, pile, and sheet pile is lower than the specification. Specification of concrete strength used for platform is $250 \mathrm{~kg} / \mathrm{cm}^{2}{ }^{13,14)}$, for pile and sheet pile is $400 \mathrm{~kg} / \mathrm{cm}^{2}{ }^{14)}$.

Depth measurement of pile and sheet pile was conducted at a location that can be reached by the inspector due to a safety reason. The result of the depth measurement of pile and sheet pile is shown in Table 4. The result shows that the pile's length is not conformed to the length specification of $22 \mathrm{~m}$. some length of sheet pile is not conformed to the length specification of $12 \mathrm{~m}$.

Structural analysis with finite element method was conducted with implementation of vertical load and horizontal load. Vertical load is a combination of dead load (D) and live load (L). Horizontal load consists of the load from water pressure and earth pressure. Vertical load used a load factor based on SNI 2847:2013, as shown in Equation 2.

\subsection{Dead Load + 1.6 Live Load}

Structural analysis was conducted using software with the finite element method, and the result of the analysis is presented in Table 5 and Figure 11.

Table 4.

Depth Measurement Results of Pile and Sheet Pile

\begin{tabular}{clcccc}
\hline No. & Test Location & $\begin{array}{c}\text { Length }(\mathrm{L}) \\
(\mathrm{m})\end{array}$ & $\begin{array}{c}\text { Used Length } \\
(\mathrm{m})\end{array}$ & $\begin{array}{c}\text { Design Length } \\
(\mathrm{m})\end{array}$ & Remark \\
\hline 1. & Pile group 2 & $4.4-5.5$ & 12.0 & 22.0 & $\mathrm{C}$ \\
2. & Pile group 3 & $12.2-13.0$ & 12.0 & 22.0 & $\mathrm{NC}$ \\
3. & Pile group 4 & $10.2-11.9$ & 10.2 & 22.0 & $\mathrm{NC}$ \\
4. & Pile 110 & 12.3 & 12.0 & 12.0 & $\mathrm{C}$ \\
\hline
\end{tabular}




\begin{tabular}{clcccc}
\hline 5. & Pile 112 & 10.0 & 10.0 & 12.0 & $\mathrm{NC}$ \\
6. & Sheet pile 1 & 10.0 & 10.0 & 12.0 & $\mathrm{NC}$ \\
7. & Sheet pile 2 & 12.1 & 12.0 & 12.0 & $\mathrm{C}$ \\
8. & Sheet pile 3 & 11.0 & 11.0 & 12.0 & $\mathrm{NC}$ \\
9. & Sheet pile 4 & 11.8 & 11.8 & 12.0 & $\mathrm{NC}$ \\
10. & Sheet pile 5 & 12.0 & 12.0 & 12.0 & $\mathrm{C}$ \\
11. & Sheet pile 6 & 10.2 & 10.2 & 12.0 & $\mathrm{NC}$ \\
12. & Sheet pile 7 & 9.9 & 9.9 & 12.0 & $\mathrm{NC}$ \\
\hline
\end{tabular}

Note:

C: conform with the specification

NC: not conform with the specification

Table 5.

Structural Analysis Results

\begin{tabular}{ccc}
\hline \multirow{3}{*}{ Component } & \multicolumn{2}{c}{ FEM Analysis } \\
\cline { 2 - 3 } & $\begin{array}{c}\text { Max Moment } \\
(\mathrm{kg} . \mathrm{m})\end{array}$ & $\begin{array}{c}\text { Max Shear Load } \\
(\mathrm{kg})\end{array}$ \\
\hline Beam & 1319 & 2828 \\
Pile & 968359 & 104488 \\
\hline
\end{tabular}

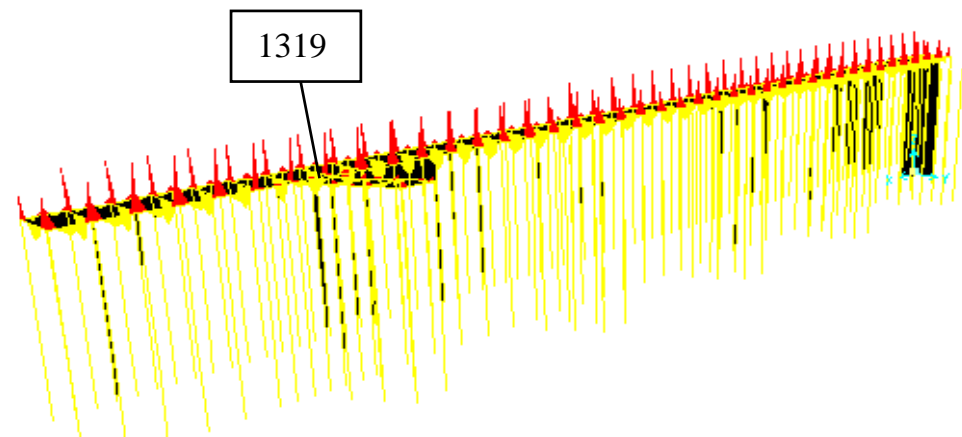

Figure 11.

Structural Analysis Results with Finite Element Method

Table 6.

Depth of Pile and Sheet Pile Penetrating Bed Rock

\begin{tabular}{cccccc}
\hline No. & Test Location & $\begin{array}{c}\text { Length }(\mathrm{L}) \\
(\mathrm{m})\end{array}$ & $\begin{array}{c}\text { Used Length } \\
(\mathrm{m})\end{array}$ & $\begin{array}{c}\text { Length of } \\
\text { penetrating soil } \\
(\mathrm{m})\end{array}$ & $\begin{array}{c}\text { Length of } \\
\text { penetrating } \\
\text { bedrock }(\mathrm{m})\end{array}$ \\
\hline 1. & Pile group 2 & $4.4-5.5$ & 12.0 & 4.8 & 2.0 \\
2. & Pile group 3 & $12.2-13.0$ & 12.0 & 4.8 & 2.0 \\
3. & Pile group 4 & $10.2-11.9$ & 10.2 & 3.0 & - \\
4. & Pile 110 & 12.3 & 12.0 & 4.8 & 0.6 \\
5. & Pile 112 & 10.0 & 10.0 & 2.8 & - \\
6. & Sheet pile 1 & 10.0 & 10.0 & 2.0 & - \\
7. & Sheet pile 2 & 12.1 & 12.0 & 4.0 & 1.2 \\
8. & Sheet pile 3 & 11.0 & 11.0 & 3.0 & 0.2 \\
9. & Sheet pile 4 & 11.8 & 11.8 & 3.8 & - \\
10. & Sheet pile 5 & 12.0 & 12.0 & 4.0 & - \\
11. & Sheet pile 6 & 10.2 & 10.2 & 2.2 & - \\
12. & Sheet pile 7 & 9.9 & 9.9 & 1.9 & - \\
\hline
\end{tabular}

Table 7.

Strength Calculation Results of Pile and Sheet Pile

\begin{tabular}{clcc}
\hline No. & Calculation & Results & Remark \\
\hline \multirow{2}{*}{ 1. } & Minimum depth of sheet pile penetrating soil $(\mathrm{m})$ & 4.598 & \multirow{2}{*}{ NO } \\
\hline \multirow{2}{*}{ 2. } & Actual depth of sheet pile penetrating soil $(\mathrm{m})$ & 2.800 & \\
\hline
\end{tabular}


The Evaluation of the causes of Retaining Wall Structure Failure at A River Based on SNI 2847:2013 (Tri Handayani, Sudarmadi)

\begin{tabular}{|c|c|c|c|}
\hline & Required moment of sheet pile (kg.m) & 20349 & \\
\hline 3. & $\begin{array}{l}\text { Vertical load design of pile group } 2 \mathrm{~m}(\mathrm{~kg}) \\
\text { Vertical load required of pile group } 2 \mathrm{~m}(\mathrm{~kg})\end{array}$ & $\begin{array}{l}13037 \\
14448 \\
\end{array}$ & $\mathrm{NO}$ \\
\hline 4. & $\begin{array}{l}\text { Self-weight moment of structure group } 2 \mathrm{~m}(\mathrm{~kg} \cdot \mathrm{m}) \\
\text { Lateral moment of structure group } 2 \mathrm{~m}(\mathrm{~kg} \cdot \mathrm{m})\end{array}$ & $\begin{array}{c}29618 \\
349417\end{array}$ & NO \\
\hline
\end{tabular}

Soil investigation data is collected from the owner engineering database, such as testing report of Standard Penetration Test $(\mathrm{SPT})^{15)}$ and Cone Penetrating Test (CPT) ${ }^{16)}$. From the testing report, it is known that the location or the depth of the hard soil. The hard soil's depth is used to estimate the length of the pile and sheet pile that penetrated to hard soil. This data is also used to calculate the strength of the pile and sheet pile. The result of the calculation is presented in Table 6 and Table 7.

The Evaluation of pile and sheet pile's strength is conducted by comparing the required strength $\left(R_{u}\right)$ and the design strength $\left(R_{n}\right)$. The strength comparison is including the force and moment. A structure is considered safe if its strength (the force and moment) is bigger than the force and moment received by the structure.

According to Table 7 , it is known that the depth of the sheet pile is less than the minimum depth requirement. The design strength of the sheet pile is less than its required strength. The vertical bearing capacity of pile groups is less than the vertical load received by pile groups. The vertical moment of the structure's self-weight is less than the horizontal moment caused by earth pressure and water pressure. That is why the structure is turned around and causes the collapse of the retaining wall structure.

Calculation results of design moment and design sheared force of beam are presented in Table 8 and Table 9.

Table 8.

\begin{tabular}{|c|c|c|}
\hline \multicolumn{3}{|c|}{ Design Mc } \\
\hline $\begin{array}{c}\text { Design } \\
\text { Moment } \\
\text { (kg.m) }\end{array}$ & $\begin{array}{c}\text { FEM } \\
\text { Result } \\
\text { (kg.m) }\end{array}$ & Remark \\
\hline 71050 & 1319 & OK \\
\hline
\end{tabular}

OK: conform with the strength requirement

Table 9.

Design Sheared Force of beam

\begin{tabular}{ccc}
\hline $\begin{array}{c}\text { Design } \\
\text { Shear } \\
\text { Force }(\mathrm{kg})\end{array}$ & $\begin{array}{c}\text { FEM } \\
\text { Result } \\
(\mathrm{kg})\end{array}$ & Remark \\
\hline 10864 & 2828 & OK \\
\hline
\end{tabular}

OK: conform with the strength requirement
Calculation results of the design moment of the pile and sheet pile are presented in Table 10 and Table 11.

Table 10.

Design Moment of the pile

\begin{tabular}{|c|c|c|}
\hline $\begin{array}{l}\text { Design } \\
\text { Moment } \\
\text { (kg.m) }\end{array}$ & $\begin{array}{l}\text { FEM Result } \\
\text { (kg.m) }\end{array}$ & Remark \\
\hline 28509 & 968359 & NO \\
\hline
\end{tabular}

Table 11. Design Moment of sheet pile

\begin{tabular}{llc}
\hline $\begin{array}{c}\text { Design } \\
\text { Moment } \\
\text { (kg.m) }\end{array}$ & $\begin{array}{c}\text { FEM } \\
\text { Result } \\
\text { (kg.m) }\end{array}$ & Remark \\
\hline 11860 & 20349 & NO \\
\hline $\begin{array}{l}\text { NO: not conform with the strength } \\
\text { requirement }\end{array}$
\end{tabular}

According to the analysis, the beam component is still in a safe condition, but for pile and sheet pile is not in a safe condition because the received load by structure is bigger than its design capacity.

\section{CONCLUSION}

Based on the analysis above and limited to the location from the testing process and evaluation, it could be concluded that there are two causes of the collapse of the retaining wall structure. The first one is the required strength $(R u)$, or the received load is bigger than its capacity or its design strength $\left(\varnothing R_{n}\right)$. Because the depth of pile and sheet pile is less than its design, the concrete strength does not meet the requirement as in the asbuilt drawing data. The second one is the vertical moment of the structure's self-weight is less than the horizontal moment caused by earth pressure and water pressure. The retaining wall structure is turned around and causing a collapse of the retaining wall structure. The retaining wall structure does not meet the SNI 2847:2013 requirement, which is the required strength $\left(R_{u}\right)$ shall lower or at least the same as the design strength $\left(\varnothing R_{n}\right)$. 


\section{ACKNOWLEDGMENT}

We would like to thank our institution National Laboratory for Structural Strength Technology (B2TKS - BPPT). B2TKS has accommodated and facilitated this research. The author would also like to thank our colleagues in B2TKS who have helped the author conducting the examination and testing for this research.

\section{REFERENCES}

1. Hardiyatmo, H.C., Teknik Fondasi 2, Beta Offset, Yogyakarta, 2006.

2. Lewis, P.R., Reynold, K., and Gagg, C, Forensic material Engineering, CRC Press, New York, 2004.

3. Wiyana, Y.E., Analisis Kegagalan Konstruksi dan Bangunan dari Perspektif Faktor Teknis, Jurnal.polines.ac.id $>$ download, Wahana TEKNIK SIPIL Vol.17 No.2 December 2012 77-86. Accessed on 8 November 2020.

4. Ishak, Analisis Kegagalan Struktur Beton Akibat Korosi Baja Tulangan, Teras Jurnal Vol.1, No.1, March 2011, https://core.ac.uk/download/pdf/236396 733.pdf Accessed on 8 November 2020.

5. Pranata, Y.A., and Elvira, L., Analisis Kegagalan Struktur Bangunan Rumah Tinggal dengan metode Elemen Hingga Linier, Jurnal Teknik Sipil Vol.12, No.3, October 2013:161-172 https://media.neliti.com/media/publicatio ns/141670-ID-analisis-kegagalanstruktur-bangunan-rum.pdf, Accessed on 8 November 2020.

6. Ismail, F.A., Identifikasi Kegagalan Struktur dan Alternatif Perbaikan serta Perkuatan Gedung BPKP Provinsi Sumatera Barat, Jurnal Rekayasa Sipil Vol.7, No.2, October 2011, jrs.ft.unand.ac.id.article.download, Accessed on November 2020.
7. Fauzan, Analisa Kegagalan Struktur dan Retrofiting Bangunan Masjid Raya Andalas Padang Pasca Gempa 30 September 2009, Jurnal Rekayasa Sipil Vol.7, No.1, February 2012, jrs.ft.unand.ac.id.article.download, Accessed on 8 November 2020.

8. Badan Standarisasi Nasional, Tata Cara Perhitungan Struktur Beton untuk Bangunan Gedung, SNI 2847:2013, 2013.

9. Triwiyono, A., Bahan Kuliah Evaluasi dan Rehabilitasi Bangunan Gedung, Magister Pengelolaan Sarana dan Prasarana Universitas Gajah Mada, Yogyakarta, 2009.

10. Triwiyono, A., Bahan Kuliah Evaluasi dan Rehabilitasi Bangunan Jalan dan Jembatan, Magister Pengelolaan Sarana dan Prasarana Universitas Gajah Mada, Yogyakarta, 2011.

11. Tomlinson, M.J., Pile Design and Construction Practise, A Viewpoint Publication, London, 2004.

12. Laboratorium Struktur dan Material, Hasil Uji Kuat Tekan Beton, Departemen Teknik Sipil Fakultas Teknik Universitas Indonesia, Jakarta, 2009.

13. NN, Data Compressive Strength, Inter Pile, Jakarta, 2008.

14. NN, Data Compressive Strength, PT. Jaya Beton, Tangerang, 2008.

15. NN, Laporan Akhir Analisis Kestabilan Lereng, PT. Sama-Sama, Tangerang, 2008.

16. NN, Laporan Akhir Penyelidikan Tanah, PT. Sama-Sama, Tangerang, 2008. 